JOSIP ZAVADA, Ph.D.

Traffic in the Cities

E-mail: josip.zavada@fpz.hr

Review

JASNA BLAŠKOVIĆ ZAVADA, Ph.D.

Accepted: June 8, 2010

E-mail: jasnab@fpz.hr

Approved: Oct. 28, 2010

KATICA MILOŠ, Ph.D.

E-mail: katica.milos@fpz.hr

University of Zagreb,

Faculty of Transport and Traffic Sciences

Vukelićeva 4, HR-10000 Zagreb, Republic of Croatia

\title{
CONDITIONS FOR IMPLEMENTING TROLLEYBUSES IN PUBLIC URBAN TRANSPORT
}

\begin{abstract}
Big cities in the world are burdened by heavy traffic and all the resulting negative consequences. A partial solution of this problem is achieved by the introduction of high-quality public urban transport of passengers that enables faster and more efficient transport. Since the introduction of individual forms of public urban transport depends on several factors, such as economic, traffic, environmental and technical ones, the problem is often a very complex one. The implementation of trolleybuses represents one of the forms of passenger transportation in public urban transport. It is the most favourable electrical vehicle for public urban transport when the implementation of a rail system is not affordable. Looking through history, the trolleybus has experienced sig nificant changes in the implementation, in a large number of world urban environments.

This paper points out the unjustifiable neglect of trolleybus in the implementation for the public urban transport and the renewed increase in the interest for its implementation. The advantages and drawbacks of the trolleybus are listed in relation to buses, as well as the reasons due to which some cities in the world are introducing it or increasing its implementation. The paper also emphasises and provides arguments of the ecological and energy advantages of trolleybuses in relation to buses as crucial in advanced public urban transport of passengers. Also, advanced technical solutions are pointed out that contribute to safer, faster and more comfortable transport of passengers.
\end{abstract}

\section{KEY WORDS}

trolleybus, bus, public urban transport, environment, economics

\section{INTRODUCTION}

The implementation of trolleybuses in public urban transport of passengers has been more disputed than any other transport means. The reason for this is that from the objective economic aspect the space of im- plementing trolleybuses is in the very narrow space between urban buses and trams. Economically justified implementation of trolleybuses is in the region of approximately 500 to 2500 carried passengers per hour [1]. Often the advantages and the drawbacks of single types of vehicles for public urban transport are not sufficiently analysed. Usually the carriers in public urban area opt for trams or buses. The buses cover those routes that would not be cost-efficient if tram traffic were traced, and for larger number of passengers that need to be carried per unit of time usually trams are implemented (not considered is the area of the number of passengers per unit of time for which also the metro would come into consideration). However, taking into consideration the increasing care for the environment, urban authorities of major European cities increasingly consider the introduction of trolleybuses in public urban transport, and the proof are marked realisations of such ideas. In order to achieve a better insight into the possibilities of implementing individual types of vehicles for public urban transport, their advantages and drawbacks will be analysed here.

The word trolleybus is of English origin, which means a bus that has trolleys for electricity supply from the overhead contact line. In America the term electric bus is used since trolley had already been used earlier for tram vehicles. The Germans use the term Oberleitungsomnibus, or shortened Obus, which means a bus with upper contact conductors for electricity supply.

\section{BASIC CHARACTERISTICS OF TROLLEYBUSES}

Since trolleybus operates on rubber pneumatics which cannot close the circuit, its electrical energy supply must be insured by two trolley poles which are in constant contact with two contact conductors ( + and -) under direct voltage of 600 or $750 \mathrm{~V}$. The 
trolleys are swivel-attached to the roof of the trolleybus and have a length of about $6 \mathrm{~m}$, which leaves to the trolleybus freedom of lateral movement of up to $4.5 \mathrm{~m}$.

Trolleybuses are usually designed as double-axle vehicles with a single body $11-12 \mathrm{~m}$ long, which has 85-115 passenger places (Figure 1), or three-axle with double-unit body (articulated), 15-18m long, which offer 145 to 180 passenger places (Figure 2). The trolleybus average operating speed is similar to the speed of buses and trams, and ranges from 15 to $35 \mathrm{~km} / \mathrm{h}$. By average usage and usual vehicle headway, the trolleybuses with a single unit body can carry 2,500 - 3,500 passengers per hour, and those with a double-unit body 4,000 - 4,500 passengers per hour. This is also the range of the transport capacity of buses, whereas the tram capacity is higher, depending on the tram design.

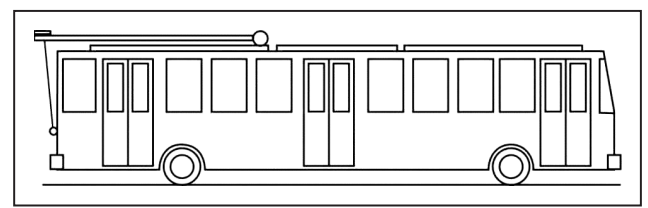

Figure 1 - Scheme of a double-axle single-unit trolleybus

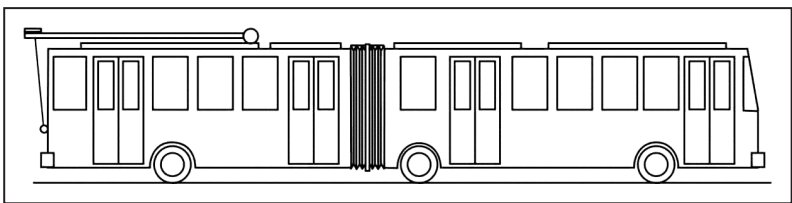

Figure 2 - Scheme of a three-axle double-unit trolleybus

Trolleybuses can be constructed also outside all these basic categories, such as double-axle with a single-unit body of smaller dimensions and capacities, double- and three-axle trolleybuses as doubledeckers with a single-unit body, trolleybuses with trailers and more recently also three-unit four-axle trolleybuses.

Comparing the characteristics of the trolleybuses and buses, the following are the advantages of trolleybuses:

- favourable traction characteristic of electric motors. This means that at low speed the electric motor achieves high torque, and with speed increase the torque gets reduced. Therefore, these vehicles do not require special power transmission that would be used for torque transformation. They have a wide range of torque and speed regulation;

- electric motor power allows overloading, which in turn enables higher acceleration and easier uphill performance;

- electric braking reduces the load and wear of friction elements of the air brake, which reduces the vehicle maintenance requirements and costs;

- possibility of applying automation in all segments of vehicle operation;

- vehicle control is simple and easy;
- environmentally friendly transport mode since it does not emit harmful combustion gases and generates very low noise;

- higher energy efficiency.

The trolleybus propulsion is usually designed with a single traction engine, and more seldom, in some articulated trolleybus designs, with two traction engines. Traction electric motors used to be direct current serial engines, and more lately they are three-phase asynchronous electric motors. In that case electric motors can be installed in the drive wheels and their number matches the number of drive wheels. The installed power per trolleybus ranges from 110 to $180 \mathrm{~kW}$. The traction force in starting the single-unit trolleybuses amounts to $22 \div 30 \mathrm{kN}$, and for articulated trolleybuses $44 \div 52 \mathrm{kN}$. The maximum speed of trolleybuses is usually $60 \mathrm{~km} / \mathrm{h}$, and less often up to $80 \mathrm{~km} / \mathrm{h}$. They can achieve average acceleration of up to $1.5 \mathrm{~m} / \mathrm{s}^{2}$ in the range of up to $70 \%$ of the maximum speed. The regulation of the traction force and speed on older trolleybuses was resistor one, and new solutions mean thyristor regulation, i.e. regulation by IGBT-semiconductors (Insulated Gate Bipolar Transistor).

Advanced propulsion solutions of trolleybuses allow its implementation also on the route sections that have not been electrified. The usage of advanced energy storage tanks, such as batteries, super capacitors or ultra capacitors or flywheels, allows trolleybus operation without supply from the contact line on the length of $3 \mathrm{~km}$. This is interesting for urban environments where it is technically impossible to electrify the tracks or in cultural and historical city districts where electrification is not allowed. Besides, trolleybus can be designed with dual-mode capability (duo-bus) which apart from electrical propulsion makes use of Diesel engine as well. Such trolleybuses use electrical propulsion on the electrified section of the route, and Diesel engine on the non-electrified part of the route. This solution allows passengers driving on longer relations without having to change e.g. from a trolleybus to a bus.

The construction of trolleybuses follows the characteristic trends of vehicle construction for public urban transport so that today's trolleybuses are of lowfloor design, enabling easier getting on and off for the passengers, and the passengers exchange at stops is faster compared to high-floor trolleybuses. Also, the manufacturers offer trolleybuses in designs with airconditioning or ventilation only.

\section{HISTORY OF TROLLEYBUS IMPLEMENTATION}

Until the mid-twentieth century, trolleybuses found significant implementation in all the major cities worldwide. They had been used instead of trams, since no 
already worn tram lines had to be replaced and new lines constructed because of the higher price. It represented a quiet and fast transport means and therefore attractive for the passengers. However, from the midtwentieth century the trend of trolleybus implementation worldwide changed. The majority of cities started to reduce the implementation of trolleybuses for public urban passenger transport without any special reason. Buses appeared that were competitive regarding price, fuel was inexpensive, and they did not need overhead contact lines. Besides, buses could operate practically on any constructed roads. Thus, buses significantly pushed out trolleybuses from the usage, covering their whole scope of application regarding the number of passengers carried per hour, which were economically covered by trolleybuses.

Historically looking, the first trolleybuses appeared at the turn of the $19^{\text {th }}$ and the $20^{\text {th }}$ centuries. Thus, the first trolleybus was introduced into operation in Spandau near Berlin in 1882, in Baltimore in 1885 , etc. In the period from 1922 to 1935 more favourable conditions were created to implement trolleybuses by improving the road infrastructure, application of experiences from automotive industry and electrical engineering in traction, which led to sudden increase in the number of trolleybuses in traffic. This refers particularly to England, Italy, France, Germany, the area of today's Czech Republic and Slovakia, Turkey, Switzerland, etc. After that period the implementation of trolleybuses increased significantly in the former USSR. In Croatia the trolleybuses were in operation in Rijeka from 1951 to 1969 and for a period also in Split.

Since 1970s the conditions on the market of energy and relation towards the environment have changed and the discussions about the implementation of trolleybuses were renewed. The fuel for buses became significantly more expensive, and environmental protection became the basic task of every producer of transport means and the traffic operator. Taking into consideration significant development of power technology, and especially of electronics and control programs, the trolleybus has become a more acceptable alternative for public urban transport.

Worldwide there are over 40,000 trolleybuses, out of which almost three quarters in Eastern European countries, first of all in Russia. Asia accounts for about 7,000, the US continent for about 3,000 and Europe for about 3,000 trolleybuses. Out of these there are about 580 in Italy, 550 in Greece, 500 in Switzerland, 380 in France and about 200 trolleybuses in Austria [2]. It is interesting is that in these countries there are more cities in which trolleybuses operate in public urban transport than cities with trams. The implementation of trolleybuses is more emphasised in Alpine countries, which have always kept trolleybuses operating in urban transport. The reason for this is primarily due to good characteristics of trolleybuses, and these are high acceleration even uphill and energy and ecological efficiency.

\section{COMPARISON ANALYSIS OF BASIC CHARACTERISTICS OF TROLLEYBUSES AND BUSES}

In the comparison of individual vehicles for public urban transport the criteria are usually set which are significant for decision-making about the implementation individual types of vehicles. These criteria are usually:

- economic,

- traffic,

- ecological, and

- technical criteria.

\subsection{Economic aspect}

The economic aspect is often the deciding one in the selection of the vehicle type since it directly influences the carrier's business success. Since usually buses operate in the area that could be covered by trolleybus operation, one should see what are the costs of introducing and implementing buses in comparison to trolleybuses.

For the introduction of buses in relation to trolleybuses with new route electrification the comparative costs are given in Table 1 using the example of Swiss conditions [3].

Table 1 - Costs of introducing buses compared to trolleybuses in millions of $\mathrm{CHF}$

\begin{tabular}{||l|c|c|c||}
\hline \hline Type of cost & Interval [min] & Bus & Trolleybus \\
\hline \hline \multirow{2}{*}{ Vehicles } & 10 & 1.20 & 2.20 \\
\cline { 2 - 4 } & 5 & 2.40 & 4.40 \\
\hline Contact line & & & 2.75 \\
\hline \multirow{2}{*}{ Total } & 10 & 1.20 & 4.95 \\
\cline { 2 - 4 } & 5 & 2.40 & 7.15 \\
\hline
\end{tabular}

There is a very big difference in the price of purchasing new vehicles. Trolleybuses are about $80 \%$ more expensive than buses. Such big difference in the price can be explained by the fact that buses are produced and ordered in much bigger batches than trolleybuses, which directly affects the production costs. This can change if the number of cities and lines with trolleybuses significantly increases, and if the manufacturers set a more flexible vehicle production according to different carriers' requirements.

In cost analysis also the time of depreciation has to be taken into consideration, which can basically differ significantly, depending on the method of exploitation, but it can be considered that the lifecycle of trolleybuses is on the average from 15 to 22 years, and 
buses from 10 to 12 years. This means almost double the time of depreciation for trolleybuses, which directly reduces the costs at an annual level.

A significant item of costs of introducing trolleybuses are the costs of installing the contact line, i.e. route electrification, which can be covered only by the transport of a greater number of passengers per unit of time (Figure 3) [1]. Number of passengers/h is maximum number in rush hours. Interval depends on the capacity of vehicles and on the number of passengers/h. This can be seen in the presentation of total costs for 10-minute and 5-minute interval. Thus the ratio of total costs for trolleybuses and buses equals 4,125 in 10-minute interval, and 2.98 in 5-minute interval.

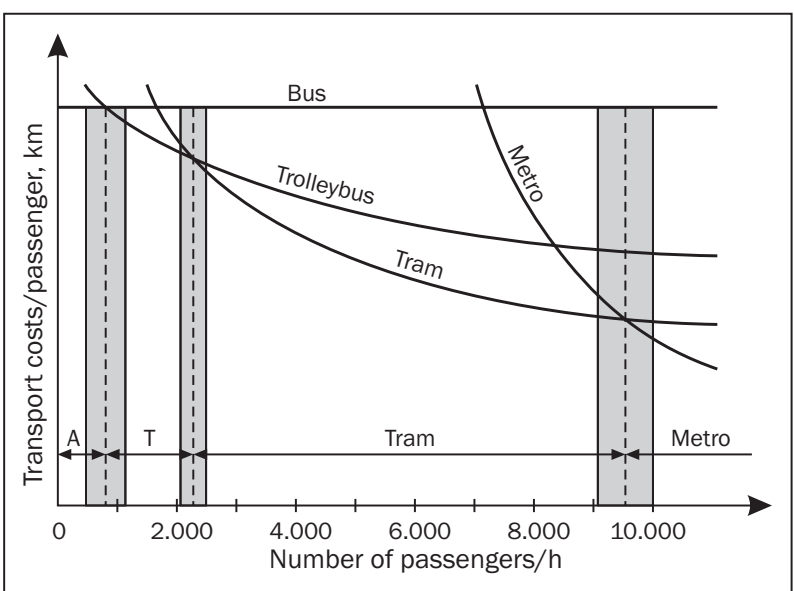

Figure 3 - Economic justification of implementing certain vehicles

However, taking into consideration different depreciation periods for vehicles and the contact line, the ratio of total costs improves in favour of trolleybuses. Thus, for the average depreciation period for buses of 11 years, trolleybuses 16 years and for contact line 22 years and by calculating also the costs of interests of $4 \%$, the introduction of trolleybuses into operation is $277 \%$ more expensive for 10 -minute interval, and $207 \%$ for 5-minute tact [3]. The depreciation time for the contact line differs per components. Thus the depreciation time for the contact wire itself is much shorter, but on the other hand the depreciation time of supporting components and stable plants is much longer. Therefore, the average depreciation time is used here.

The costs analysis of using certain types of vehicles shows that the costs of propulsion and maintenance per kilometre of ride are somewhat higher (about 7\%) for trolleybus than for the bus (Table 2) [3]. This results primarily from the increased fixed operating costs for the trolleybus contact wire. In variable costs the energy costs for the trolleybus are somewhat lower than for the buses, which with adequate energy pricing policy could be even more favourable for trolleybuses. The difference between the total fixed and operating costs is somewhat lower due to very high share of costs of the persons employed in the operation realization, which are the same in both systems.

Table 2 - Operating costs with included maintenance costs in CHF per $\mathrm{km}$ of ride

\begin{tabular}{|c|c|c|c|}
\hline \multicolumn{2}{|r|}{ Costs } & Bus & Trolleybus \\
\hline \multirow{3}{*}{$\begin{array}{l}\text { D্ } \\
\text { ix } \\
\text { ix }\end{array}$} & Operating for vehicles & 0.40 & 0.50 \\
\hline & Operating for contact wire & & 0.40 \\
\hline & Total operating & 0.40 & 0.90 \\
\hline \multirow{4}{*}{$\frac{\frac{0}{0}}{\frac{0}{\frac{\pi}{2}}} \frac{}{\frac{10}{70}}$} & Energy & $0.30 \div 0.38$ & $0.30 \div 0.34$ \\
\hline & For the employed & 5.50 & 5.50 \\
\hline & Average & 0.70 & 0.70 \\
\hline & Total operating & $6.50 \div 6.58$ & $6.50 \div 6.54$ \\
\hline \multicolumn{2}{|c|}{$\begin{array}{l}\text { Overall fixed and } \\
\text { variable costs }\end{array}$} & $6.90 \div 6.98$ & $7.40 \div 7.44$ \\
\hline
\end{tabular}

Taking into consideration all the costs presented in Tables 1 and 2 (investment costs of introducing a system + operating costs with included maintenance costs) and their reduction to a $\mathrm{km}$ of ride in 5-minute tact, approximately CHF 7.75 per $\mathrm{km}$ of ride for bus and 9.15 per $\mathrm{km}$ of ride for the trolleybus are obtained [3], which is a difference of about $18 \%$.

Considering economic reasons only, the presented results make many carriers in the public urban transport in the world to opt for the introduction of buses instead of trolleybuses, although it refers to the number of passengers per hour that should be carried by trolleybuses.

In making a deeper analysis of energy costs, i.e. benefits $(\eta)$ of single systems, the trolleybuses have the advantage. This should have an increasing significance in the future, regarding the more expensive energy and its availability in the future. For a more complete insight, the benefits $(\eta)$ of single assemblies and devices and total benefit for the bus (with hydromechanical gearbox and with electric power transmission) and for the trolleybus (Table 3) are given [4]. Trolleybuses have the possibility of energy return into the contact line during braking, which significantly contributes to energy saving and represents an advantage compared to buses. However, on modern buses the electric power transmission has started to be installed, which also enables the conversion of kinetic energy during braking into electric energy, which can be stored into adequate electric energy tanks (batteries or ultra capacitors). However, this solution does not allow recovery of energy to the extent to which it does in trolleybuses. It can be seen from the table that the efficiency with recovery, in relation to power increases in buses with electric power transmission from 0.42 to 0.504 , and in trolleybuses for energy power plants (thermal power plants using stone coal) with efficiency from 0.60 to 0.81 . When this efficiency increase is translated into energy saving, then recovery in buses 
Table 3 - Efficiency of individual assemblies and devices on buses and trolleybuses

\begin{tabular}{|c|c|c|c|c|}
\hline \multicolumn{2}{|c|}{ Device } & $\begin{array}{l}\text { Bus with hydro- } \\
\text { dynamic gearbox }\end{array}$ & $\begin{array}{l}\text { Bus with electrical } \\
\text { power transmission } \\
\text { (electrical gearbox) }\end{array}$ & Trolleybuses \\
\hline \multicolumn{2}{|c|}{ Diesel engine (DE), power plant } & $0.42-\mathrm{DE}$ & $0.42-\mathrm{DE}$ & 0.60 - el. power plant \\
\hline \multicolumn{2}{|c|}{ Efficiency with energy recovery } & - & 0.504 & 0.81 \\
\hline \multicolumn{2}{|c|}{ High-voltage grid $150 \div 380 \mathrm{kV}$} & - & - & 0.98 \\
\hline \multicolumn{2}{|c|}{ High-voltage grid $6 \div 150 \mathrm{kV}$} & - & - & 0.98 \\
\hline \multicolumn{2}{|c|}{ Transformer + rectifier } & - & - & 0.97 \\
\hline \multicolumn{2}{|c|}{ Contact line (600 V - DC) } & - & - & 0.95 \\
\hline \multirow{5}{*}{$\begin{array}{l}\text { Power } \\
\text { transmission }\end{array}$} & \multirow{3}{*}{ Gearbox } & 0.93 - hydromechanical & 0.93 - generator + rectifier & - \\
\hline & & - & 0.98 - IGBT inverter & 0.98 - IGBT inverter \\
\hline & & - & 0.93 - electric motor & 0.93 - electric motor \\
\hline & Universal shaft & 0.99 & 0.99 & 0.99 \\
\hline & Main gear & 0.95 & 0.95 & 0.95 \\
\hline \multicolumn{2}{|c|}{ Power transmission total } & 0.875 & 0.797 & 0.857 \\
\hline \multicolumn{2}{|c|}{ Total from drive to wheels } & 0.367 & 0.335 & 0.455 \\
\hline \multicolumn{2}{|c|}{ Energy saving by recovery } & - & $20 \%$ & $35 \%$ \\
\hline
\end{tabular}

with electric power transmission realises about $20 \%$ of energy saving, and in trolleybuses about $35 \%$ of energy saving.

Total efficiency of the entire chain of conversion and transmission of energy from the energy source (in Diesel engines it is diesel fuel, and in trolleybuses it is stone coal which is used for powering of thermal power plants to obtain electricity) to wheels, for buses with hydromechanical gearbox amounts to 0.367 , for buses with electrical power transmission 0.335, and for trolleybuses 0.455 . This means greater total efficiency of trolleybuses by $24 \%$ compared to bus with hydromechanical gearbox and by $36 \%$ compared to buses with electrical power transmission.

Considering the EU region it should be mentioned that the electricity market deregulation has been carried out, which has led to the reduction in the price of electricity of up to $60 \%$ for big consumers [5]. It is to be believed that in the future the price of electricity could fall, having in mind the excess of production capacities and increased competition. On the other hand, the oil price is relatively high on the world market, and it is expected only to rise in the future. Such energy price trends on the world market give chance to the electrically powered public urban transport vehicles in relation to those powered by oil-based fuels.

In the European countries the public urban transport has been deregulated. This allows various carriers to join this transport mode. What they look for primarily is to realise profit in this activity. Since public urban transport is not a profitable activity, the incentives from the city are required. Profitability in public urban transport of passengers is difficult to realise due to keeping the schedule regardless of the number of passengers carried at certain intervals, and due to a relatively large number of persons who have free ride or a discount price (schoolchildren, senior citizens, disabled persons, etc.). If public transport using electrical vehicles is to be organised in the city, then the introduction of trolleybuses is a solution with lowest investments. The problem of more expensive vehicles in relation to buses can be solved by a bigger fleet and long-term concession. The trolleybus manufacturers are expected a higher level of standardisation and greater competitiveness in order to reduce the price of vehicles. The introduction of trolleybuses would give incentive also to the environmental standards for the city centres in which traffic should be allowed only for the vehicles with zero harmful emissions.

\subsection{Traffic aspect}

Comparing the mentioned systems according to the given criteria, it could be said that the smallest differences are in the traffic aspect. The buses and trolleybuses are, namely, regarding the traffic and technical characteristics of very similar features. Regarding external and internal appearance, regarding dimensions, the number of passenger seats, net and gross mass, axle loading, average operating speed and similar. A significant difference lies in the acceleration and the possibility of overcoming ascents, which results from the favourable traction characteristic of the electric motor and the possibility of pulling sufficient quantities of electricity from the contact line. Trolleybuses pass crossroads and/or curves with small radius with a bit lower speed than buses. 


\subsection{Ecological aspect}

The ecological aspect refers primarily to the comparison of harmful emissions generated by individual vehicles into the environment and the level of noise in traffic.

Trolleybuses represent environmentally friendly vehicles that do not generate harmful emissions, if only the area of vehicle movement is considered. However, regarding trolleybus in a wider context, i.e. taking into consideration the production of electrical energy required for trolleybus propulsion, the condition may be significantly different depending on the source of electricity.

Harmful emissions generated by buses depend on their age and technical condition, primarily the Diesel engine itself and its devices. The emissions of new buses are limited by regulations that are in force at the time of bus production, e.g. Euro3, Euro4, Euro5. The fact is that every new standard stipulates significant reduction of the allowed harmful emissions, primarily of nitrogen oxide (NOx) and particulates. Thus, at the moment Euro5 standard is in force (permitted emissions for heavy Diesel engines are: $1.5 \mathrm{~g} / \mathrm{kWh}$ for $\mathrm{CO}$, $0.46 \mathrm{~g} / \mathrm{kWh}$ for $\mathrm{HC}, 2.0 \mathrm{~g} / \mathrm{kWh}$ for $\mathrm{NO}_{\mathrm{x}}$ and $0.02 \mathrm{~g} /$ kWh for particulates), and from 2015 the introduction of Euro6 standard is planned with significant reduction of the permitted emissions in relation to Euro5 (1.5 g/ kWh for $\mathrm{CO}, 0.13 \mathrm{~g} / \mathrm{kWh}$ for $\mathrm{HC}, 0.4 \mathrm{~g} / \mathrm{kWh}$ for $\mathrm{NO}_{\mathrm{x}}$ and $0.01 \mathrm{~g} / \mathrm{kWh}$ for particulates) [6]. This means that in the future buses will generate less and less harmful emissions, i.e. they will become environmentally friendlier. However, there is the fact that buses will never achieve zero harmful emissions like trolleybuses, regardless of whether the engine uses diesel as fuel, bio-diesel or it is a gas engine.

The mentioned ecological advantage of trolleybuses compared to buses can have a crucial influence in the selection of the type of vehicle for public urban transport. It is especially in the cities where atmosphere is heavily loaded by harmful components. Condition for that is sufficient numbers of passengers for trolleybuses and that the introduction of trams or metros is not cost-efficient. The introduction of trolleybuses may reduce the additional environmental pollution. The decision about possible implementation of trolleybuses should be stimulated by tax policy or adequate incentives by municipal and government authorities so that the carriers could find economical justification for that.

The ecological advantage of trolleybuses in relation to buses is reflected also in the aspect of noise. Trolleybus is quieter for the level of noise which is in case of buses increased by the operation of the Diesel engine. This characteristic is especially emphasised on routes with uphill sections when the Diesel engine operates at higher loads and generates greater noise. This ad- vantage comes to the fore also on routes through prevalently residential areas in which lower level of noise is a requirement.

\subsection{Technical aspect}

For the introduction of trolleybuses it is necessary to have available sufficient amounts of electricity at an affordable price and that for the trolleybus route planning there are technical conditions for setting the contact line, electric traction substations and for their supply of high-voltage contact line.

The specific characteristic of trolleybuses compared to tram or metro is that it operates on rubber pneumatics along the road, unlike trams or metros that run on steel wheels along steel rails. This affects significantly the method of energy supply and grounding. Since the electrical circuit cannot be closed on a trolleybus through the wheels, the contact wire has to consist of two conductors (+ and -). Due to the impossibility of grounding through the wheels, the electrical equipment has to have additional insulation (usually triple insulation), particularly close to the doors and other places where passengers may come into contact with high voltage. A part of electrical equipment, namely, is under high voltage conducted from the contact line, and amounts to 600V or $750 \mathrm{~V}$. Such additional measures for the safety of passengers against electric shock increase the weight of the vehicle and its price.

Until 1980s the trolleybuses had been equipped with vehicle speed regulation devices, which meant additional losses of electrical energy on regulation resistances. This was followed by the period of introducing semi-conductor elements into regulation devices to change voltage on traction electric motors, i.e. for vehicle speed regulation. First thyristors were used, then GTO- thyristors and more recently IGBT-transistors. In this way the consumption of electrical energy was reduced by about $40 \%$ if recovery of electrical energy is used, i.e. up to $30 \%$ of the received energy.

The dependence of trolleybuses on the contact line can be reduced by fitting Diesel engines. This solution may be with Diesel engine of smaller power (45 to 80 $\mathrm{kW}$ ) when this engine is used only for the transport of the vehicle itself (no passengers) to the depot, i.e. workshop or in some other cases.

The full significance of the Diesel engine on the trolleybus comes to the fore when the power ranges from 150 to $400 \mathrm{~kW}$. Then it is called a duobus that can operate with similar performances as a trolleybus powered by electricity or as a bus powered by a Diesel engine (Figure 4) [5]. Here an electric gear is used, i.e. Diesel engine powered by a generator, and the obtained electricity is used to supply the traction electric motors. This enables continuous transfer of the torque 


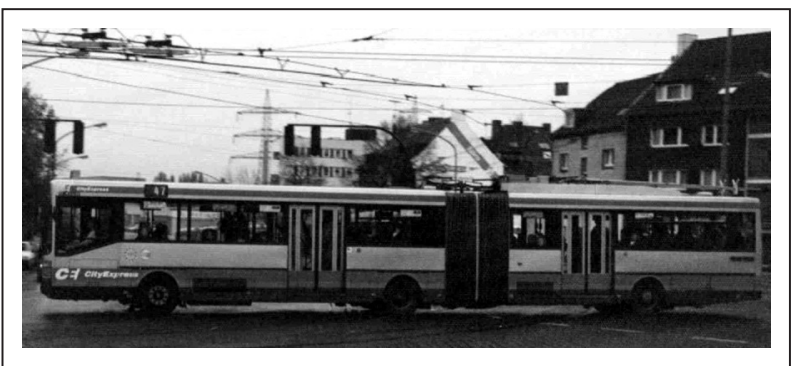

Figure 4 - Duobus Mercedes-Benz in Essen in Diesel operation regime (trolley poles down)

without discontinuities and jumps, and in braking the kinetic energy can be converted into electrical energy.

If duobus is equipped with a device for storing electricity in the bus operating regime, then the braking energy can be used and stored in the form of electricity which can then be re-used in vehicle acceleration. This is an additional way of saving the diesel fuel.

The basic disadvantage of duobuses is the increased price and weight due to the Diesel engine and additional devices required for such a solution.

The advantages of duobuses are reflected most when driving through more densely populated parts of urban areas requiring no harmful emissions and lower noise. Then the duobus operates as a trolleybus, provided the route is electrified. In less densely populated urban areas, where the problem of harmful impact on the environment is not so much emphasised, and where the electrification of the route would not be cost-efficient due to the insufficient number of passengers, the duobus can operate as a bus.

Trolleybuses can be equipped also by control guiding device that assists the driver in controlling the vehicle along the line, enables higher average operating speeds, contributes to better positioning of the vehicle and increases safety. In the future, driverless operation is planned using the guidance devices.

The basic form of guidance is the mechanical system that is usually designed so that the trolleybus is fitted with small horizontal wheels that are in contact

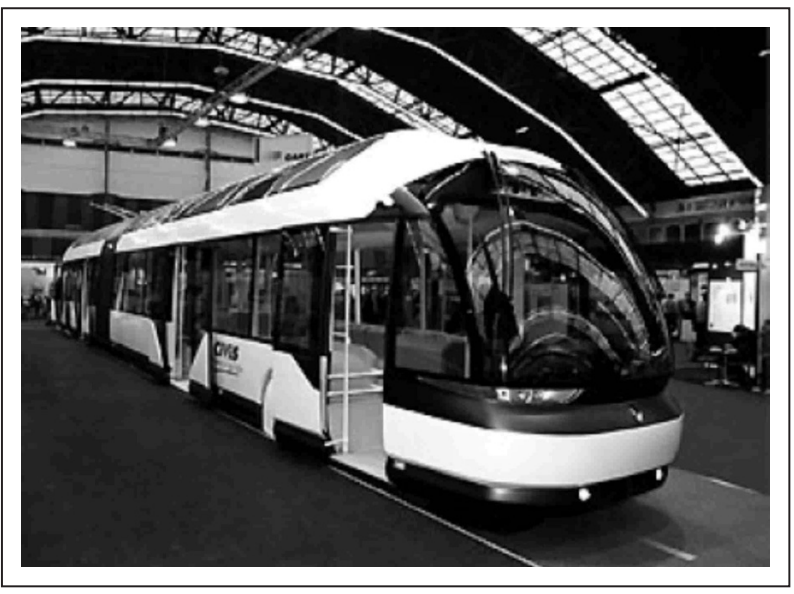

Figure 5 - Trolleybus Renault-Matra CiViS laterally on adequate guides on the route and thus guide the trolleybus along a route.

Another method of mechanical guidance is by installing a small vertical wheel which is guided along a rail set on the road along the running route.

The electronic guidance system is based on the implementation of electronic sensors that follow the road markings. The markings can be in the form of a magnetic tape when the sensors operate on the principle of induction or a certain colour/paint when the sensors operate on the optical principle. An example of a modern trolleybus with optical guidance is Renault-Matra CiViS (Figure 5) [5]. Basically, such a trolleybus requires a segregated running route with special markings. The trolleybus can drive without the optical guidance also, along a non-marked route, and the transition is seamless without reducing the average operating speed. For the needs of short-period drive without supply from the contact line, the battery supply is used. Usually this may be in case of driving to the depot or a workshop.

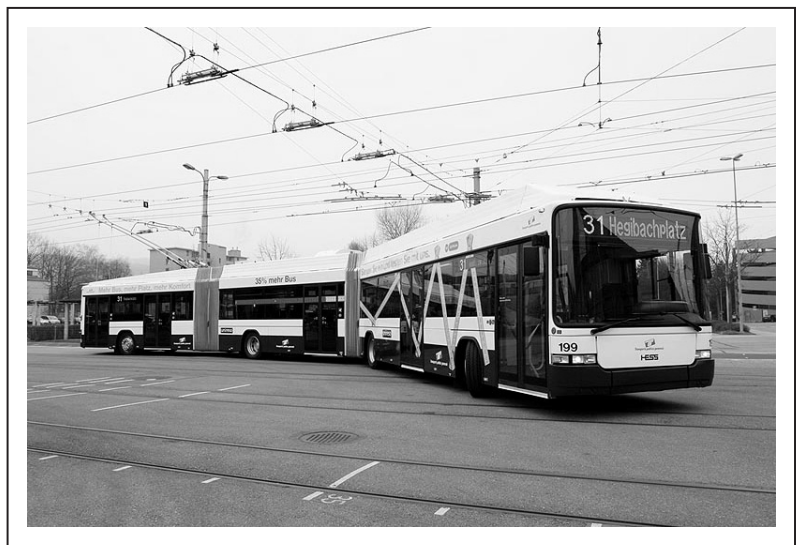

Figure 6 - Three-unit bi-articulated trolleybus

In searching for new trolleybus design solutions, the companies NAW/HESS/Siemens-Swisstrolley 1 have made a reconstruction of the existing two-engine articulated trolleybus by adding one more part to the body and an additional articulated unit. This resulted in a three-unit bi-articulated trolleybus that is $24 \mathrm{~m}$ long and popularly called Megatrolley (Figure 6) [7]. The trolleybus has the second and the third drive axle with doubled wheels, and the first and the fourth are controlled by individual wheels. It has 63 seats and 138 standing places. Following the experimental drive in Genf and Zürich, these cities have ordered a new series of such trolleybuses for regular exploitation.

Trolleybuses of such dimensions and capacities are intended for the transport or a large number of passengers on lines whose routes enable its operation regarding its dimensions and configuration. At the maximum angle of turn of the driving wheels, this bi-articulated trolleybus requires the maximum turn circle of $24,090 \mathrm{~mm}$ in diameter, and the minimum of 


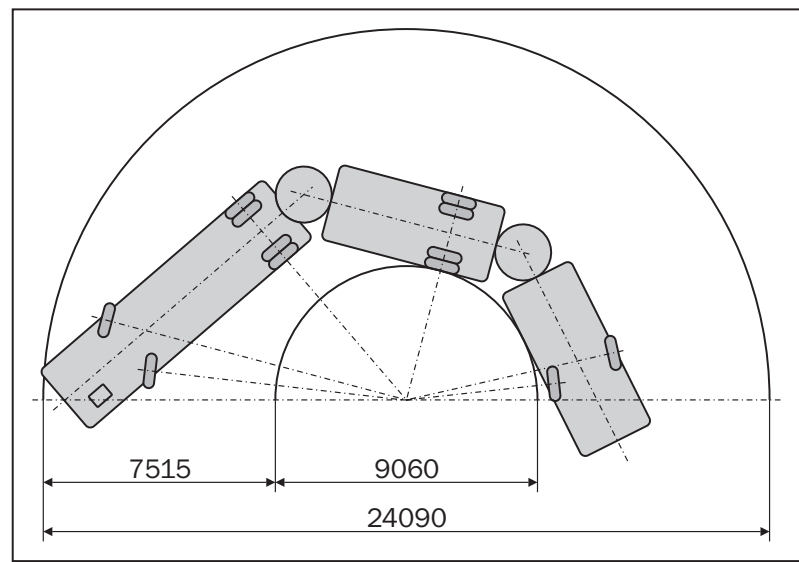

Figure 7 - Required dimensions of free passage for turning of the bi-articulated trolleybus

$8060 \mathrm{~mm}$, i.e. the passage width of $7,515 \mathrm{~mm}$ (Figure 7) [7].

\section{CONCLUSION}

Trolleybuses find their application in the transport of passengers in public urban transport in the range of the number of transported passengers per unit of time which is between the buses and trams, and amounts to about 500 to 2,500 passengers/h. The assumption for this is for the trolleybuses to be produced in large batches like buses for their price to be competitive, or to find other solutions that would cover the higher price of trolleybus production which is the result of small batches. This can be justified by the fact that trolleybuses are environmentally and energy friendlier transport means than buses, having in mind the general tendencies of environmental protection and energy savings.

Trolleybuses may be said to be the most favourable electrical transport means in public urban transport of passengers, if the introduction of some rail system for the transport of passengers is not economically justified.

The introduction of trolleybuses requires a sufficiently big network of routes and dimensions of the fleet in order to ensure the economy of transport and the necessary flexibility of service. Due to the mentioned advantages of trolleybuses, the municipal authorities should find a way to subsidize the higher price of vehicles and costs of constructing and maintaining the contact line.

The implementation of the technical solutions on vehicles and operating routes can increase the frequency of trolleybus rides, improve the driving safety and comfort for passengers. The barriers to introducing trolleybuses for public urban transport of passengers will be eliminated with greater awareness of environmental protection and energy savings and by introducing adequate legal regulations.

\section{Dr. sc. JOSIP ZAVADA}

E-mail: josip.zavada@fpz.hr

Dr. sc. JASNA BLAŠKOVIĆ ZAVADA

E-mail: jasnab@fpz.hr

Dr. sc. KATICA MILOŠ

E-mail: katica.milos@fpz.hr

Sveučilište u Zagrebu, Fakultet prometnih znanosti

Vukelićeva 4, 10000 Zagreb, Republika Hrvatska

\section{SAŽETAK}

\section{UVJETI ZA PRIMJENU TROLEJBUSA U JAVNOM GRADSKOM PRIJEVOZU}

Veliki gradovi u svijetu vrlo su opterećeni prometom i svim negativnim posljedicama koji iz toga proizlaze. Djelomično rješenje tog problema postiže se uvođenjem kvalitetnog javnog gradskog prijevoza putnika koji bi im omogućio brži $i$ efikasniji prijevoz. S obzirom na to da uvođenje pojedinih oblika javnog gradskog prijevoza ovisi o više čimbenika, kao što su ekonomski, prometni, ekološki i tehnički, problem je često vrlo složen. Primjena trolejbusa predstavlja jedan oblik prijevoza putnika u javnom gradskom prijevozu. On je najpovoljnije električno vozilo za javni gradski prijevoz kada se ne isplati primjena nekog tračničkog sustava. Gledano kroz povijest, trolejbus je doživljavao naglašene promjene $u$ primjeni u velikom broju svjetskih urbanih sredina.

$U$ ovom radu se ukazuje na neopravdano zanemarivanje trolejbusa u primjeni za javni gradski prijevoz te ponovni porast zanimanja za njegovu primjenu. Navode se prednosti $i$ nedostaci trolejbusa u odnosu na autobus, kao i razlozi zbog kojih ga pojedini gradovi u svijetu uvode ili povećavaju njegovu primjenu. Naglašava se i argumentira ekološka i energetska prednost trolejbusa u odnosu na autobus kao ključna u suvremenom javnom gradskom prijevozu putnika. Također se ističu suvremena tehnička rješenja koja doprinose sigurnijem, bržem i udobnijem prijevozu putnika.

\section{KLJUČNE RIJEČI}

trolejbus, autobus, javni gradski prijevoz

\section{LITERATURE}

[1] Zavada, J.: Vozila za javni gradski prijevoz, FPZ, Zagreb, 2006

[2] Zabel, R.: Trolleybusse in Schweizer und anderen Ballungsräumen, Stand und Perspektiven - Teil 1, eb, Vol. 103, No. 8, 2005, 390-400

[3] Martin, P.: Die Wirtschaftlichkeit des Trolleybusses, volkswirtschaftliche und betriebswirtschaftliche Aspekte. Referat auf 20. schweizerischer Trolleybustagung, 10.09.2003. Luzern

[4] Hondius, H.: Wo steht der Trolleybus in der wesentlichen Welt?, Stadtverkehr, Vol. 53, No. 10, 2008, 6-11

[5] Björklund, S., Soop, C., Rosenqvist, K., Ydstedt, A.: New Concepts for Trolley Buses in Sweden, KFB-Rapport:70, ScanTech, Development AB, www.kfb.se/ pdfer/R-00-70.pdf

[6] http://www.dieselnet.com/standards/eu/hd.php

[7] Hondius, H.: Doppelgelenkt-Elektrobusse von HESS/ Vossloh Kiepe, stadtverkehr, Vol. 52, No. 10, 2007, 10-19 